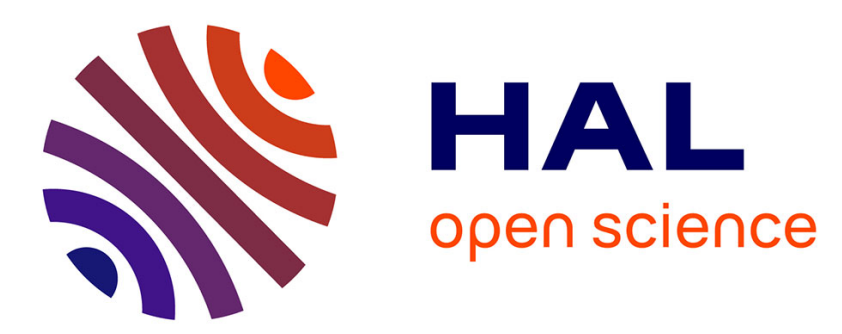

\title{
The social, educational and cognitive factors of success in the first year of university: A case study
}

Sophie Morlaix, Bruno Suchaut

\section{To cite this version:}

Sophie Morlaix, Bruno Suchaut. The social, educational and cognitive factors of success in the first year of university: A case study. International Review of Education, 2014, 60 (6), pp.841-862. 10.1007/s11159-014-9459-4 . halshs-01141499

\section{HAL Id: halshs-01141499 \\ https://shs.hal.science/halshs-01141499}

Submitted on 13 Feb 2018

HAL is a multi-disciplinary open access archive for the deposit and dissemination of scientific research documents, whether they are published or not. The documents may come from teaching and research institutions in France or abroad, or from public or private research centers.
L'archive ouverte pluridisciplinaire HAL, est destinée au dépôt et à la diffusion de documents scientifiques de niveau recherche, publiés ou non, émanant des établissements d'enseignement et de recherche français ou étrangers, des laboratoires publics ou privés. 


\section{The social, educational and cognitive factors of success in the first year of university: A case study}

\section{Sophie Morlaix • Bruno Suchaut}

Abstract: The main objective of this study, which evaluated a sample of first-year students enrolled at the University of Burgundy, France, in 2010-2011, is to understand the factors determining success in the first year of university. The originality of this research lies in the inclusion of specific indicators of students' skills when they start university within the explanatory models of educational achievement. These indicators include measures of academic performance (written comprehension skills) and cognitive abilities. While the impact of cognitive abilities on educational success has been examined at primary level in France, the present study is among the first to do this at higher education level, with the additional consideration of students' educational and social backgrounds. The results show the significant impact of educational background (repeated years, type of baccalaureate and baccalaureate grade) on success. The researchers also found that written comprehension skills and cognitive abilities alone play a limited role in explaining success, since the impacts of these variables are apparent throughout a student's educational career (and not just in higher education). Another finding was that subject choice based on specific career aspirations is an important factor associated with success - a significant insight which qualifies the impact of educational background.

Keywords Assessment and evaluation - Higher education - Skills - Academic success - France

Résumé : La présente étude, qui évalue un échantillon d'étudiants inscrits en première année 2010-2011 à l'université de Bourgogne (France), a pour objet de cerner les facteurs déterminant la réussite de la première année universitaire. L’originalité de cette recherche réside dans la prise en compte, dans le cadre des modèles explicatifs du niveau d'instruction, d'indicateurs spécifiques sur les compétences que possèdent les nouveaux étudiants. Ces indicateurs comprennent la mesure des performances intellectuelles (compréhension écrite) et des capacités cognitives. Si l'impact des capacités cognitives sur la réussite scolaire est examiné en France au niveau primaire, la présente étude est une des premières à en faire de même au niveau supérieur, en intégrant en outre le contexte éducatif et social des étudiants. Les résultats révèlent l'impact significatif sur la réussite du contexte éducatif (années de redoublement, type de baccalauréat et note obtenue à celui-ci). Les chercheurs constatent en outre que la compréhension écrite et les capacités cognitives jouent à elles seules un rôle limité dans l'explication de la réussite, puisque l'impact de ces variables est manifeste tout au long du parcours éducatif (et pas seulement au niveau supérieur). Il apparait par ailleurs que le choix de la discipline fondé sur des aspirations concrètes de carrière est un facteur important de succès, et constitue une découverte importante qui relativise l'impact du contexte éducatif.

Mots clés : Facteurs sociaux, éducatifs et cognitifs de succòs pendant la première année universitaire : étude de cas 


\section{Introduction}

The problem of students' failure in their first years of university remains a major issue in France. The target of ensuring that 50 per cent of members of the same age group achieve a higher education qualification has yet to be achieved. A recent study found that one out of every three students drops out of the course they enrolled in by the end of the first or second year (MESR 2010). In recent years, the university student population has become increasingly diverse in terms of social, cultural and economic capital, but also in terms of age and nationality. This increasing diversity of the student population has intrigued many educational researchers, and various explanatory factors have been identified to account for failure in the first year of university. According to Alain Coulon (1997), "access to and success in higher education are determined by a process of learning and cultural integration, and those who are unable to become affiliated fail" ${ }^{1}$.The process of cultural integration (in terms of acclimatisation to academic culture) is thought to determine the transition from school to university and to shape the acquisition of a new identity (the transition from pupil to student). According to Coulon, students who drop out of university are those who are unable (or too slow) to understand and internalise the codes of university culture. In seeking to cope with their new “job”, some students fail to recognise the demands of university study (Beaupère and Boudesseul 2009; Astin 1984; Tinto 1993). The capacity to adapt to university life and study is thought to be determined by students' characteristics at the beginning of their university education, which are linked to a range of personal and educational variables.

Recent studies on the factors of success at university have highlighted the impact of students' educational background and social origin (Beaupère and Boudesseul 2009). Research has shown that holders of a science baccalaureate (Bac S) perform better than other students. By contrast, students who have repeated a year at secondary level and hold a technical (Bac Techno) or vocational baccalaureate (Bac Pro) ${ }^{2}$ are more likely to fail (Prouteau 2009). There is also evidence to suggest that female students perform better at university than male students, in particular because of their greater ability to comply with the norms of academic study and their better organisational skills (Frickey and Primon 2002). Beyond these social and educational factors, the conditions of study (in particular individual study time) are also key variables linked to success. For example, research by the French Centre for Research Qualifications (Centre d'Études et de Recherche sur les Qualifications; CEREQ) ${ }^{3}$ and the national Observatory of Student Life (Observatoire de la Vie

\footnotetext{
${ }^{1}$ All translations from French sources such as this one were prepared by the authors of this paper

2 Students in France complete their secondary school cycle by passing a baccalaureate diploma exam (baccalaure'at, often abbreviated bac). There are three kinds of bac, namely (1) the baccalaure'at ge'ne'ral [general baccalaureate, with three subject streams: S (sciences), ES (economic and social studies) and L (literary studies); (2) the baccalaure' at technologique [technical baccalaureate, with seven streams: STG (management), STI (industrial studies), STL (scientific an technological laboratory studies), STSS (health and social studies), STAV (agronomy), TMD (music and dance) and Ho^ tellerie (hotel management)] and (3) the baccalaure'at professionnel (vocational baccalaureate) with several streams.
}

3 For more information (in English) about

http://www.cereq.fr/index.php/themes/Versionanglaise/A-public-pole-of-expertise.

CEREQ, see 
Etudiante; OVE) ${ }^{4}$ has shown that taking on a job in college can be beneficial in terms of professional integration, but may also be a risk factor - for example, if the workload is greater than part-time, if the student works for more than six months per year or if the job has little to do with the subject studied at university. If there is a conflict between study and work, the risk of failure will be higher (Béduwé and Giret 2004).

As shown by Marie Duru-Bellat (1995), other more contextual factors may also contribute to failure among first-year university students. The impact of the broader university context such as the location of the university, the nature of its teaching practices, the content of university curricula, and support structures must be taken into account in order to explain success in year one (Romainville 2000 ; Michaut 2003). A wide range of policies have been implemented to ensure that as many students as possible pass their first year (pre-selection based on ability, performance-related fees, introduction of individually tailored courses to give more freedom to students, etc.). The French government initially focused on plans to ensure that students are able to change courses at university and that additional support is available (for example in the form of extra tutoring). These policies have had mixed results (Danner 2000; Borras 2011), largely because of the difficulty of reaching weak students. New measures have been introduced since 2007 as part of a national scheme designed to improve undergraduate students' academic achievement (the Plan Réussite en Licence; PRL). However, studies have shown that the measures aimed at providing greater methodological and pedagogical support to students generally fail to reach their target audience - the students most in need of support. The students attending extra classes tend to be those who already have a high chance of success and who are already to some extent familiar with the norms of academic study. These findings have been confirmed in a recent study by Rébecca Shankland (2009), who found that most of the students who performed well at university had also performed well at secondary level and were from families where parents had some form of higher education.

The objective of our study was to extend previous research on the determinants of academic achievement, but also to introduce an additional factor of success. The general hypothesis is that success at university is determined by personal variables such as cognitive abilities and academic level. But students' levels of performance also appear to be linked to other characteristics (both social and educational) and partly account for the difficulties encountered by some students in their first year at university.

The impact of cognitive abilities on educational success has been examined at primary level in France (Barrouillet et al. 2008), but never at higher education level. In addition to measuring cognitive ability (working memory, speed of information processing, and logical reasoning), we assessed students' level of academic performance by way of a written comprehension test. In our analysis of the weight of each set of factors in determining success we hope to provide useful information about students' chances of success (or their risk of failure) based on their personal characteristics.

\section{Methodology}

\footnotetext{
${ }^{4}$ For more information about OVE, see http://www.ove-national.education.fr/the-ove/presentation.
} 
Our study is based on a sample of first-year students enrolled at the University of Burgundy in 2010-2011. Although it would have been preferable to include students in all subjects, the material constraints involved in this type of research (in particular in terms of conducting the tests) are such that we had to confine ourselves to a smaller sample. Our sample included subjects with a relatively diverse student population in terms of educational background (type of baccalaureate), with a specific focus on first-year students enrolled in Law, Social Business Studies (Administration Économique et Sociale; AES), and Psychology. The number of students enrolled in these three courses in September 2010 was 1,493, representing 35 per cent of the total number of students enrolled in year one at the University of Burgundy. Table 1 compares the sample population to the entire student population enrolled in year one in terms of several characteristics.

Even though we had already limited our sample to students studying one of our three selected subjects, it was also impossible to test all of these students in all areas. So we asked for volunteers and got 616 students to take part in the logical reasoning and written comprehension tests (both tests were administered in a "pen and paper" form). Our assessment of cognitive abilities applied to a smaller sample since the tests required small groups (one student per computer) and more time. In total, data relating to all of the academic and cognitive indicators are available for 421 students. Figure 1 shows the statistical relationships we examined in our study. 
Table 1 Students enrolled in the three courses (Law, AES and Psychology) compared to the entire cohort of year 1 students enrolled at the University of Burgundy, France (\%)

\begin{tabular}{|c|c|c|c|c|c|c|}
\hline & & & Law & $\begin{array}{l}\text { Social Business } \\
\text { Studies (AES) }\end{array}$ & Psychology & Total year 1 \\
\hline $\begin{array}{l}\text { Absolute student numbers } \\
\text { (18 March 2011) }\end{array}$ & & & 857 & 318 & 437 & 4,274 \\
\hline \multirow[t]{21}{*}{ Baccalaureate stream } & \multicolumn{6}{|c|}{ General baccalaureate (Bac S, Bac ES and Bac L) } \\
\hline & $\mathrm{S}$ & Sciences & 18.7 & 6.6 & 20.8 & 28.3 \\
\hline & ES & Economic and social studies & 42.1 & 37.7 & 18.5 & 25.9 \\
\hline & $\mathrm{L}$ & Literary studies & 18.8 & 3.1 & 19.7 & 19.4 \\
\hline & STT & Tertiary science and technology & 9.3 & 25.2 & 13.3 & 9.2 \\
\hline & Foreign & Baccalaureate completed abroad & 4.1 & 8.5 & .5 & 4.2 \\
\hline & \multicolumn{6}{|c|}{ Vocational baccalaureate (Bac Pro) } \\
\hline & PRO & Vocational baccalaureate & 3.2 & 12.6 & 5.3 & 3.5 \\
\hline & PRO agri & Vocational agriculture & .0 & .3 & 2.1 & .3 \\
\hline & \multicolumn{6}{|c|}{ Technical baccalaureate (Bach Techno) } \\
\hline & STSS & Health and social studies & .7 & 1.6 & 14.0 & 2.9 \\
\hline & STI & Industrial studies & .7 & 2.8 & 1.6 & 2.2 \\
\hline & STL & Scientific and technological laboratory studies & .5 & .3 & 1.6 & 1.4 \\
\hline & SMS & Medical social sciences & .5 & .9 & .7 & .4 \\
\hline & STAV & Agronomy & .0 & .0 & .7 & .4 \\
\hline & ST agri & Scientific and technological agriculture & .0 & .0 & .0 & .0 \\
\hline & F11 Musique & Techniques of music & .0 & .0 & .2 & .1 \\
\hline & F12 Art & Applied arts & .0 & .0 & .2 & .0 \\
\hline & Hôtellerie & Hotel management & .0 & .3 & .0 & .1 \\
\hline & \multicolumn{6}{|l|}{ Alternatives } \\
\hline & DAEU & National university entry diploma equivalent to bac & .5 & .0 & .7 & .4 \\
\hline
\end{tabular}




\begin{tabular}{|c|c|c|c|c|c|c|}
\hline & & & Law & $\begin{array}{l}\text { Social } \\
\text { Business } \\
\text { Studies (AES) }\end{array}$ & Psychology & Total year 1 \\
\hline & Capacité & $\begin{array}{l}\text { Alternative bac-equivalent } \\
\text { national university entry diploma }\end{array}$ & .7 & .0 & .0 & .1 \\
\hline & Dispense & Exemption & .2 & .0 & .2 & .1 \\
\hline & International & International baccalaureate (IB) & .1 & .0 & .0 & .0 \\
\hline & Information $n$ & ilable & .0 & .0 & .0 & .9 \\
\hline Age when completing & Under 18 & & 3.5 & 1.0 & 1.6 & 3.7 \\
\hline \multirow[t]{5}{*}{ the baccalaureate } & 18 & & 63 & 43.4 & 47.2 & 56.7 \\
\hline & 19 & & 22.2 & 29.1 & 30 & 24.2 \\
\hline & 20 & & 7.6 & 15.2 & 12.9 & 8.3 \\
\hline & Over 20 & & 3.7 & 11.3 & 8.3 & 4.2 \\
\hline & Information $\mathrm{n}$ & ilable & & & & 2.7 \\
\hline \multirow{8}{*}{$\begin{array}{l}\text { Level of passing the } \\
\text { baccalaureate } \\
\text { (grade) }\end{array}$} & $\mathrm{P}$ & $\begin{array}{l}\text { passable } \\
\text { (pass without honours) }\end{array}$ & 27.9 & 34.6 & 30.2 & 27.9 \\
\hline & $\mathrm{AB}$ & assez bien & 20.5 & 13.5 & 13.5 & 17.5 \\
\hline & & (honours) & & & & \\
\hline & $\mathrm{B}$ & bien & 7.7 & 2.8 & 2.7 & 6.5 \\
\hline & & (pass with merit) & & & & \\
\hline & TB & très bien & 1.9 & 0.3 & 0.2 & 2.0 \\
\hline & & (distinction) & & & & \\
\hline & Information $n$ & ilable & 42.0 & 48.7 & 53.3 & 46.1 \\
\hline Sex & Female & & 63 & 52.2 & 80.8 & 57.7 \\
\hline Scholarship & Yes & & 45.6 & 58.8 & 51.7 & 47.8 \\
\hline
\end{tabular}


Table 1 continued

\begin{tabular}{|c|c|c|c|c|c|}
\hline & & Law & $\begin{array}{l}\text { Social Business } \\
\text { Studies (AES) }\end{array}$ & Psychology & Total year 1 \\
\hline \multirow{9}{*}{$\begin{array}{l}\text { Socio-professional category: } \\
\text { father's occupation }\end{array}$} & Farmer & 3.5 & 1.6 & 3.0 & 3.2 \\
\hline & $\begin{array}{l}\text { Craftsman, shopkeeper, employer, freelance } \\
\text { worker or company director }\end{array}$ & 9.2 & 8.2 & 8.5 & 8.3 \\
\hline & Higher managerial and professional occupations & 26.1 & 13.5 & 16.2 & 21.8 \\
\hline & Intermediate occupations & 14.4 & 9.1 & 17.2 & 15.0 \\
\hline & Employee & 14.4 & 18.2 & 15.1 & 14.5 \\
\hline & Blue-collar worker & 16.9 & 24.8 & 22.0 & 19.1 \\
\hline & Retired & 6.9 & 10.7 & 6.4 & 7.1 \\
\hline & Not working & 4.4 & 5.7 & 3.2 & 3.6 \\
\hline & Information not available & 4.2 & 8.2 & 8.5 & 7.4 \\
\hline
\end{tabular}




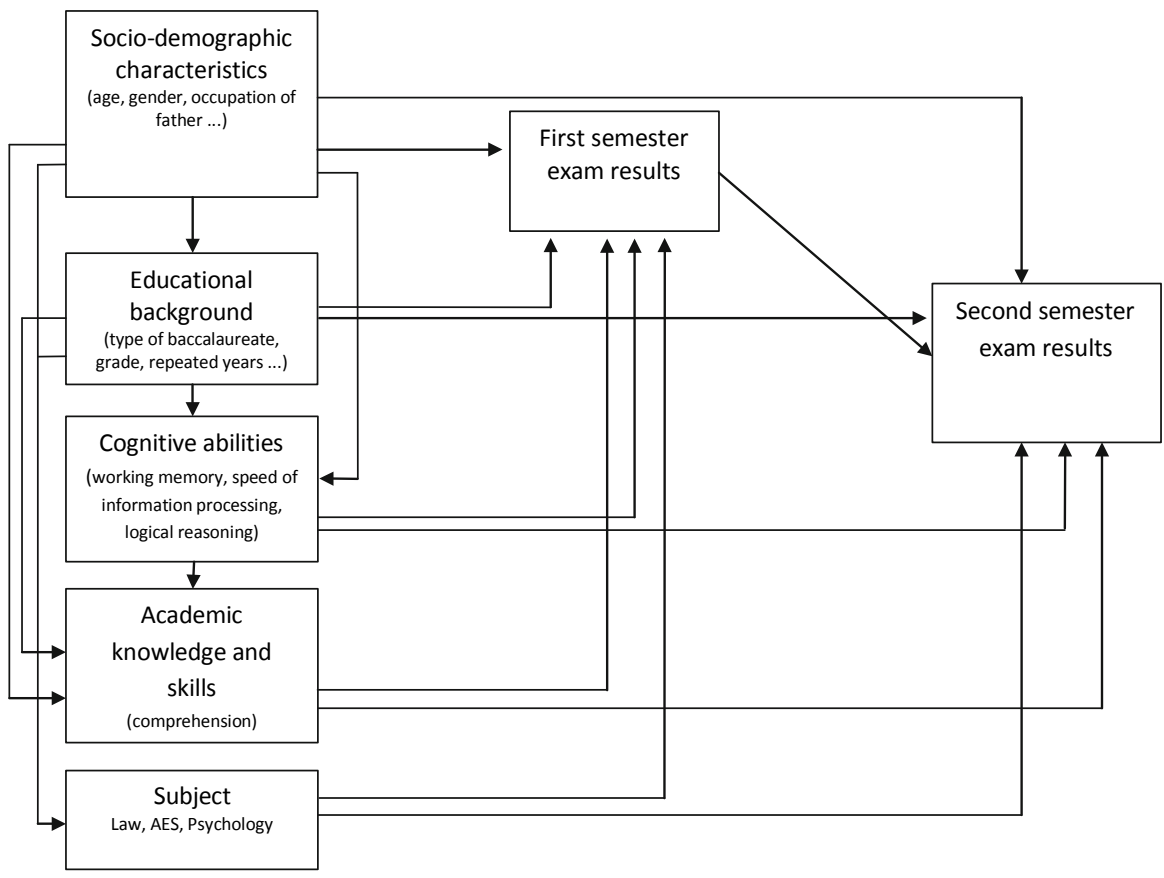

Fig. 1 Relational structure of success in year 1

The level of first-year students' academic knowledge at the beginning of the first semester (particularly in written comprehension) was measured using the DALF test (Diplôme Approfondi en Langue Française) ${ }^{5}{ }^{5}{ }^{5}$ Three cognitive skills were measured: working memory, speed of processing and logical reasoning. Working memory was measured using three indicators: reading span, operation span and working memory span based on the Time-Based Resource Sharing (TBRS) model $^{6}{ }^{6}$. Speed of information processing was also measured, using three indicators: a simple reaction task and two tasks adapted from research by Michael Posner (both complex detection tasks) ${ }^{7}{ }^{7}$ The cognitive tests were adapted from American tests such as the reading span task (Daneman and Carpenter 1980) and the operation span task (Turner and Engle 1989), while speed of processing was measured by replicating Posner's tasks. The working memory tasks were developed

based on the structure of

\footnotetext{
${ }^{5}$ The DALF test (Diplôme Approfondi en Langue Française) is an advanced-level French language proficiency test. For more information see http://www.ciep.fr/en/delf-prim-delf-delf-junior-version-dalfdiplome-detudes-langue-francaise-diplome-approfondi-langue/dalf-diplome-approfondi-langue-francaise

${ }^{6}$ The Time-Based Resource Sharing (TBRS) model "accounts for working memory spans in adults [...]. [It] assumes that both components (i.e., processing and maintenance) of the main working memory tasks require attention and that memory traces decay as soon as attention is switched away" (Barouillet et al. 2004, p. 83).

${ }^{7}$ American psychologist Michael Posner is known for his research on the role of attention in high-level human tasks such as visual search, reading and number processing
} 
the computerised tasks from the TBRS model. Finally, reasoning skills were measured using Raven's progressive matrices (RPM). ${ }^{8}$ Measurements were performed on three cognitive abilities for each participant. Additional data were collected in February following the first exam session in order to obtain the detailed results of students in each module (unité d'enseignement ; UE). The students were also asked to complete a questionnaire on their conditions of study, type of accommodation (paid work, study methods, study time, motivation, etc.). At the end of the academic year, we also collected final results.

\section{The determinants of academic performance}

\section{Regression model 1: testing written comprehension using DALF}

All of the students included in the sample took the "C1"-level tests of the DALF, which focused on written comprehension. The test was based on a text by Guy de Maupassant ${ }^{9}$ (approximately 2,000 words). The students were asked to answer roughly ten questions by commenting on or analysing specific passages. The written comprehension component of the DALF includes 13 items. These items contribute to an overall score. The highest possible score is 22. The average score of our sample was 12.9, with a standard deviation of 3.6. The distribution is Gaussian. We found that male and female students achieved similar scores. There were also no differences in terms of their type of accommodation or between scholarship students and other students. By contrast, the children of fathers in managerial and professional occupations achieved better results than other students (2 points higher than students from working-class backgrounds). The variables related to educational background were discriminating. Significant differences were found in terms of baccalaureate type (technical and vocational baccalaureate holders obtained the lowest scores), overall grade (students who achieved at least a mention assez bien ${ }^{10}$ in their baccalaureate were at a distinct advantage) and the age of students passing the same qualification (students who were two years behind achieved significantly lower scores). We estimated a regression model (model 1) to provide an overall picture of the determinants of success. Only the significant variables were included (Table 2). The type of baccalaureate and the overall grade obtained in the baccalaureate had the highest coefficients, since vocational baccalaureate holders scored lowest in written comprehension (1.6 points less than holders of a general baccalaureate). The included variables account for less than 10 per cent of the variance of scores in the DALF tests $\left(\mathrm{R}^{2}=0.09\right)$.

\footnotetext{
8 Originally developed by English psychologist John C. Raven in 1936, this test consists of 60 nonverbal multiple-choice questions designed to measure a person's reasoning ability (see http://www.raventest.net/).

${ }^{9}$ Guy de Maupassant (1850-1893) is especially renowned for his cleverly-plotted short stories, but he also wrote a number of novels, poems and some travel literature

10 The pass mark for the baccalauréat is at 10 out of 20 points. Above that, there are three levels of honours: A result of 12-13.99 points will earn a mention assez bien (honours); 14-15.99 points a mention bien (pass with merit); and 16-20 points a mention très bien (distinction)
} 
Table 2 Analysis of variance of DALF scores $(\mathrm{N}=612)$

\begin{tabular}{lllll}
\hline Reference category & Active category & \multicolumn{3}{l}{ Model 1: Written comprehension } \\
\cline { 3 - 5 } & & Coefficient & Student's t & Prob. \\
\hline Constant & $? 13.0$ & $? 63.6$ & 0.00 \\
$\begin{array}{l}\text { Age at baccalaureate } \\
19 \text { or under }\end{array}$ & Over 19 & -0.9 & -1.92 & 0.05 \\
$\begin{array}{l}\text { Type of baccalaureate } \\
\text { General baccalaureate }\end{array}$ & Bac Techno & & & \\
Grade/Distinction & Bac Pro & -1.0 & -2.7 & 0.00 \\
$\begin{array}{l}\text { Pass (without honours) } \\
\text { Occupation of father }\end{array}$ & Honours (AB, B or TB) & $? 1.2$ & -2.6 & 0.00 \\
Other occupation & Higher managerial and & $? 0.6$ & 1.6 & 0.00 \\
$\mathrm{R}^{2}$ & professional occupations & & 0.0 & 0.08 \\
\hline
\end{tabular}

The determinants of cognitive abilities

Regression model 2: measuring reasoning skills using RPM

Reasoning skills were measured using a shortened version of Raven's progressive matrices (RPM). Participants used computers to complete some of these tasks. Our reduced version contained 23 "problems" to solve. In each problem, the participants were shown 8 numbers and were required to continue the sequence (or pattern) by selecting the correct number from 8 other numbers. In addition to visual-spatial ability, the Raven test measures working memory, speed of information processing, fluid intelligence and induction (Huteau and Lautrey 1999; Jensen 1987), as well as various spatial skills. The Raven scores have a Gaussian distribution and vary from 1 to 20, with an average of 9.4 and a standard deviation of 3.4.

The factors explaining the variance of Raven scores based on student characteristics are shown in Table 3. The model accounts for 13 per cent of the variance of the results. Variables such as age, type of baccalaureate, baccalaureate grade, and the occupation of the fathers were found to have a significant impact. Even among students with similar characteristics, we found that the chosen subject made a significant difference, since Psychology students scored almost half a point more than AES and Law students. A more surprising result was the impact of the type of accommodation. Students living in university halls were at a distinct disadvantage (high probability of error: $8 \%$ ).

Measuring working memory: reading span (regression model 3), operation span and TBRS

This study used tests involving verbal material (Barrouillet et al. 2007) and visualspatial material (Vergauwe et al. 2014). Three measures of working memory are 


\begin{tabular}{|c|c|c|c|c|}
\hline \multirow{3}{*}{ Reference category } & \multirow{3}{*}{ Active category } & \multirow{2}{*}{\multicolumn{3}{|c|}{ Model 2: Reasoning skills }} \\
\hline & & & & \\
\hline & & Coefficient & Student's t & Prob. \\
\hline \multirow{2}{*}{\multicolumn{2}{|c|}{$\begin{array}{l}\text { Constant } \\
\text { Age at baccalaureate }\end{array}$}} & +8.1 & +31.2 & 0.00 \\
\hline & & & & \\
\hline \multirow{2}{*}{\multicolumn{5}{|c|}{$\begin{array}{l}19 \text { or under } \\
\text { Type of baccalaureate }\end{array}$}} \\
\hline & & & & \\
\hline Other type of baccalaureate & Bac S & +1.7 & +4.9 & 0.00 \\
\hline \multicolumn{5}{|l|}{ Grade/Distinction } \\
\hline Pass (without honours) & Honours (AB, B or TB) & +0.5 & +1.1 & 0.09 \\
\hline \multicolumn{5}{|l|}{ Occupation of father } \\
\hline \multirow[t]{3}{*}{ Other occupation } & Blue-collar worker & +0.8 & +2.4 & 0.02 \\
\hline & Farmer, freelance worker & +0.9 & +2.3 & 0,02 \\
\hline & $\begin{array}{l}\text { Higher managerial and } \\
\text { professional occupations }\end{array}$ & +1.0 & +2.8 & 0.00 \\
\hline \multicolumn{5}{|l|}{ Type of accommodation } \\
\hline Other type of accommodation & University halls & -0.6 & -1.7 & 0.08 \\
\hline \multicolumn{5}{|l|}{ Subject } \\
\hline AES and Law & Psychology & +1.4 & +5.0 & 0.00 \\
\hline $\mathrm{R}^{2}$ & & & 0.13 & \\
\hline
\end{tabular}

recognised as being better predictors than previous measures (Barrouillet et al. 2008; Lépine et al. 2005). We measured working memory using three indicators: reading span, operation span and TBRS. In the reading span task, participants were asked to memorise numbers. Between each number, the participants were asked to read sentences and to assess their plausibility. The score was the percentage of memorised numbers. The average score was 81, with a standard deviation of 16 . The included variables explained 8 per cent of the variance of the results $\left(\mathrm{R}^{2}=0.08\right)$ (see Table 4).

The average score of female students was 6 points lower than the average score of male students. Having repeated one or several years before entering higher education and/or having a scholarship were also key factors with a negative impact on students' scores.

In the operation span tasks (model not presented), participants were asked to memorise letters. Between each letter, participants were shown equations and were asked to assess the accuracy of the result (correct or incorrect). The regression models confirmed some of the findings of the previous model (reading span), in particular the lower performance of female students and older students. Other factors such as the type of baccalaureate and the type of accommodation also had an impact on performance (holders of a science baccalaureate and students not living in university halls were at an advantage).

In the TBRS test (model not presented), participants were asked to memorise letters and to determine the parity of the numbers. The percentage of variance 
Table 4 Analysis of variance of reading scores $(\mathrm{N}=418)$

\begin{tabular}{|c|c|c|c|c|}
\hline \multirow[t]{2}{*}{ Reference category } & \multirow[t]{2}{*}{ Active category } & \multicolumn{3}{|c|}{ Model 3: Reading span } \\
\hline & & Coefficient & Student's t & Prob. \\
\hline Constant & & +84.7 & +40.5 & 0.00 \\
\hline Male & Female & -6.2 & -3.3 & 0.00 \\
\hline Non-scholarship students & Scholarship students & -4.9 & -3.2 & 0.00 \\
\hline Age at baccalaureate & & & & \\
\hline 19 or under & Over 19 & -6.3 & -3.8 & 0.00 \\
\hline Subject & & & & \\
\hline Psychology and Law & AES & -6.8 & -2.4 & 0.00 \\
\hline $\mathrm{R}^{2}$ & & & 0.08 & \\
\hline
\end{tabular}

explained by student characteristics was approximately 10 per cent. Compared to the previous tests, the occupation of the father also contributed to explaining the variance in performance since the children of fathers in intermediate occupations were found to be at an advantage. It is important to note that at this level of education, a social selection has already occurred so that it is difficult to compare these results with those obtained at lower education levels. In fact, in the French educational system, the children of managers (executives) and members of the liberal professions constitute almost a third of the students at university. As access to higher education has progressed for all the social categories since 1991, the proportion of the children of workers and lower-level employees entering university has risen from 20 to 39 per cent, for children of senior executives or intermediate occupations the increase was from 50 to about 80 per cent. The stagnation, even reduction of the success rate from the end of 1990s is striking, including children from disadvantaged backgrounds who do not catch up with their more privileged peers.

\section{Measuring speed of information processing}

Speed of information processing was measured using three indicators: serial reaction time (SRT), and our two Posner tasks, Posner 1 and Posner 2 (complex reaction time; CRT). ${ }^{11}$ The tasks for these tests were carried out using computers. In the SRT task, participants were asked to press the space bar as quickly as possible when a square appeared on the screen. The squares appeared 1,000, 2,000 or 3,000 ms after the signal. In Posner 1, two letters were shown side by side on the screen and the participants were asked to indicate whether they were physically identical. Posner 2 involved a CRT task. Two letters were shown side by side on the screen and participants were asked to indicate whether they were identical, irrespective of whether they were capital letters or lowercase letters. The data collected in the three tasks indicate average millisecond values.

\footnotetext{
${ }^{11}$ Serial reaction time (SRT) investigates cognitive and biological principles of (implicit) learning and memory during a series of repetitive tasks. Complex reaction time (CRT) looks at how people make several decisions about when and how to respond when they are set one complex task
} 
Table 5 Correlations in the speed of information processing tasks $(\mathrm{N}=418)$

\begin{tabular}{lll}
\hline & Raven & Working memory \\
\hline Working memory & $? 0.23^{* * *}$ & \\
Speed of information processing & $-0.14^{* * *}$ & $-0.24^{* * *}$ \\
\hline
\end{tabular}

*** significant at a $1 \%$ threshold

The three models (not presented) indicate similar percentages of explained variance, which remain low (3-4\%), therefore, in terms of speed of information processing, there were very few discriminating variables. In the SRT task, female and mature students performed less well. Science baccalaureate holders achieved higher levels than other students. In Posner 1, the children of blue-collar workers achieved lower scores than other students. However, the most discriminating factors were gender (with male students achieving higher levels) and type of baccalaureate (with holders of a vocational baccalaureate achieving lower scores). In Posner 1, Psychology students had slower reaction times than other students, as did the children of blue-collar workers. Scholarship students and vocational baccalaureate holders obtained lower scores than non-scholarship students and holders of a general or technical baccalaureate.

To provide more general measures, we then needed global indicators corresponding to the two targeted abilities (working memory and speed of information processing. We calculated the correlations between the different measures to ensure that the grouping was valid. The correlations were positive and significant (1\% threshold), although their intensity varied. The strongest correlation was between Posner 1 and Posner 2 (?0.63). The average scores in working memory and speed of information processing were calculated. Each score took account of performance in each area, yielding three measures of cognitive ability: Raven, working memory and speed of information processing. Table 5 shows the correlations between the three measures.

The correlations were generally low. The lowest correlation was between Raven and speed of information processing $(-0.14)$, which suggests that the three dimensions of cognitive ability have an autonomous component which needs to be taken into account in the analysis of the determinants of success.

\section{Analysis of the factors explaining the variance of results in the first semester}

At the end of the first semester, Law and AES students were assessed in three modules (UEs), while Psychology students were required to pass four UEs. In each of the three subjects, the correlations between the UE grades were high (generally above 0.70), suggesting that the average grade in the first semester can be taken as a general indicator of student performance. The overall average in the first semester was close to 9 out of 20 in the three subjects. However, since the various courses differ significantly in terms of curricula, these levels of success in each course are not really comparable. We were aware that this bias would need to be taken into account when using the average grade for the sample as a whole. We therefore used the chosen subject as a control variable in the regression models, measuring the 
impact of student characteristics based on "identical chosen subject"

Table 6 Analysis of variance of first semester results $(\mathrm{N}=612)$

\begin{tabular}{|c|c|c|c|c|c|c|c|}
\hline \multirow[t]{2}{*}{ Reference category } & \multirow[t]{2}{*}{ Active category } & \multicolumn{2}{|c|}{$\begin{array}{l}\text { Model 4: } \\
\text { (excluding } \\
\text { DALF and } \\
\text { Raven) }\end{array}$} & \multicolumn{2}{|c|}{$\begin{array}{l}\text { Model 5: } \\
\text { (excluding } \\
\text { Raven) }\end{array}$} & \multicolumn{2}{|c|}{$\begin{array}{l}\text { Model 6: } \\
\text { (accepting } \\
\text { all variables } \\
\text { as } \\
\text { explanatory) }\end{array}$} \\
\hline & & Coef. & Prob. & Coef. & Prob. & Coef. & Prob. \\
\hline Constant & & +3.8 & 0.00 & +2.1 & 0.00 & +2.2 & 0.00 \\
\hline \multicolumn{8}{|l|}{ Subject } \\
\hline \multirow[t]{2}{*}{ Law } & AES & +2.4 & 0.00 & +2.4 & 0.00 & +2.4 & 0.00 \\
\hline & Psychology & +2.5 & 0.00 & +2.5 & 0.00 & +2.5 & 0.00 \\
\hline Male & Female & +0.2 & 0.33 & +0.2 & 0.39 & +0.2 & 0.41 \\
\hline $\begin{array}{l}\text { Students who repeated one } \\
\text { or several years at } \\
\text { secondary level }\end{array}$ & $\begin{array}{l}\text { Students who did not } \\
\text { repeat a year at } \\
\text { secondary level }\end{array}$ & +0.6 & 0.00 & +0.7 & 0.00 & +0.7 & 0.00 \\
\hline Non-scholarship students & Scholarship students & -0.4 & 0.02 & -0.4 & 0.02 & -0.4 & 0.03 \\
\hline \multicolumn{8}{|l|}{ Type of baccalaureate } \\
\hline \multirow[t]{4}{*}{ Bac Pro } & Bac Techno & +0.9 & 0.03 & +0.7 & 0.09 & +0.7 & 0.09 \\
\hline & Bac L & +2.7 & 0.00 & +2.3 & 0.00 & +2.3 & 0.00 \\
\hline & Bac ES & +3.2 & 0.00 & +2.9 & 0.00 & +2.9 & 0.00 \\
\hline & Bac S & $+4,4$ & 0.00 & +3.9 & 0.09 & +4.0 & 0.00 \\
\hline Pass (without honours) & Honours (AB, $\mathrm{B}$, or TB) & +2.3 & 0.00 & +2.1 & 0.00 & +2.1 & 0,00 \\
\hline \multicolumn{2}{|c|}{ Written comprehension (DALF) } & & & +0.15 & 0.00 & +0.15 & 0.00 \\
\hline \multicolumn{2}{|l|}{ Raven’s test (\% of success) } & & & & & -0.00 & 0.68 \\
\hline \multicolumn{2}{|l|}{$\mathrm{R}^{2}$} & 0.40 & & 0.43 & & \multicolumn{2}{|l|}{0.43} \\
\hline
\end{tabular}

The first factor we examined was cognitive ability. Several models (not presented) were estimated using the different measures of cognitive ability. We found that performance in working memory and speed of information processing tasks had no impact on university results. By contrast, the Raven test score was found to have a positive impact (positive and significant coefficient). For example, a 25 per cent increase of the success rate in the Raven test resulted in a 0.5 point increase of the average score, which is not insignificant.

Global models (Table 6) were also estimated by including all student characteristics, accounting for 40 per cent of the variance of grades at the end of the first semester (model 4). While we found no difference between male and female students, age seemed to have a significant impact (students who had repeated one or several years before entering higher education were less likely to succeed). The fact 


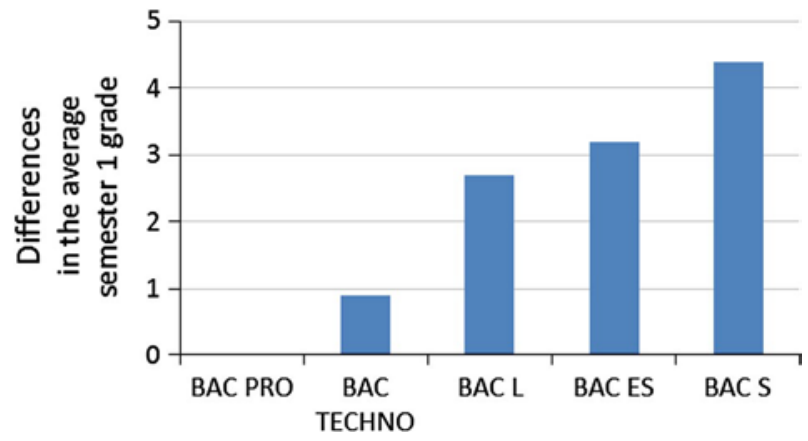

Fig. 2 Net effects of type of baccalaureate on the average grade in the first semester BAC $\mathrm{PRO}=$ Vocational baccalaureate BAC TECHNO = Technical baccalaureate BAC L = Baccalaureate in Literary studies BAC ES = Baccalaureate in Economics and Social sciences BAC S = Baccalaureate in Sciences

of being a scholarship student (which amounts to a social characteristic) was also associated with lower success rates (almost half a point less on average).

The type of baccalaureate was by far the most discriminating factor, accounting for 24 per cent of the variance of the results. Models 4, 5 and 6 showed that the different types of baccalaureate were associated with different levels of success, with vocational baccalaureate holders achieving the lowest levels of performance. Science baccalaureate holders (Bac S) achieved the best results, followed by holders of a baccalaureate in economics and social sciences (Bac ES) and (finally) holders of a baccalaureate in literary studies (Bac L). The differences were significant, since there was a 4-point difference between vocational baccalaureate (Bac Pro) and science baccalaureate holders (Bac S) (Figure 2).

For an equivalent type of baccalaureate, the fact of passing with honours was also associated with significant differences in student performance: students who had passed their baccalaureate with honours scored on average 2 more points than other students. A difference of over 6.5 points in the average grade at the end of the first semester was found between students with a vocational baccalaureate (Bac Pro) who had repeated at least one year at secondary level and students who held a science baccalaureate (Bac S) and had passed with honours. These results confirm the significant impact of educational background on success at university (Prouteau 2009).

Model 5 (Table 6) provides significant data. At the margins of the impact of these factors, academic level was shown to have an independent impact on student performance. The value of the coefficient (?0.15) indicates that between two students with a standard deviation of difference in the DALF test (standard deviation of DALF scores: 3.6 points), the difference in the average grade obtained in the first semester was more than half a point $\left(3.6^{*} 0.15\right)$. Logical reasoning performance had no specific impact on student results. The coefficient associated with the Raven variable has a null value (model 6). Therefore, cognitive ability was found to have no independent impact on performance. The results suggest that students' cognitive abilities were mainly expressed in their prior education. 
Table 7 Logistic model of success in the first semester $(\mathrm{N}=612)$

\begin{tabular}{llllc} 
& Active category & \multicolumn{2}{c}{$\begin{array}{c}\text { Model 7: Probability } \\
\text { of success in semester 1 }\end{array}$} \\
& & Coef. & Prob. & Exp. \\
\hline Constant & & -5.2 & 0.00 & 4.8 \\
Subject & & & & \\
Law & AES & +2.0 & 0.00 & 7.2 \\
& Psychology & +1.3 & 0.00 & 3.8 \\
Male & Female & +0.0 & 0.81 & 1.1 \\
Students who repeated one & Students who did not repeat & +0.5 & 0.06 & 1.6 \\
$\quad$ or several years at secondary level & a year at secondary level & & & \\
Non-scholarship students & Scholarship students & -0.2 & 0.34 & 0.8 \\
Type of baccalaureate & & & & \\
Bac Pro & Bac Techno & -0.4 & 0.44 & 0.6 \\
& Bac L & +1.0 & 0.05 & 2.8 \\
& Bac ES & +1.4 & 0.00 & 4.3 \\
& Bac S & +2.6 & 0.00 & 10.5 \\
Pass (without honours) & Honours (AB, B, or TB) & +1.6 & 0.00 & 5.1 \\
Written comprehension (DALF) & & +0.10 & 0.00 & 1.1 \\
Raven's test (\% of success) & & +0.00 & 0.28 & 1.0 \\
Nagelkerke's R & & 0.37 & & \\
\hline
\end{tabular}

Regression model 7: estimating the probability of success

Another way of measuring success at the end of the first semester is to reason in terms of probability of success or failure. Across the sample as a whole, the proportion of students who passed their exams at the end of the first semester in January (i.e. students who scored at least 10 out of 20) was 32 per cent. We estimated a logistic regression model (Table 7) which included the same explanatory factors as model 6 . The regression result of this model confirmed the results of our previous models.

The figures in the "Exp" column of model 7 (Table 7) show the odds ratios associated with the coefficients. The results indicate that a student with a science baccalaureate (Bac S) was 10.5 times more likely to pass his or her first-semester exams than a student with a vocational baccalaureate (Bac Pro). Likewise, students who passed their baccalaureate with honours were 5.1 times more likely to pass their first semester than students who did not pass their baccalaureate with honours. The DALF score also had an impact, since students who achieved high scores were found to be more likely to succeed in their first-semester exam. By contrast, cognitive ability measured by the Raven test did not appear to be an independent discriminating factor.

Other data collected using questionnaires were used to assess the more subjective 
dimensions of the conditions of access to university (in particular, subject choice after the baccalaureate). Fifty-eight per cent of the participants stated that they had chosen their subject based on specific career aspirations; 48 per cent stated that their choice was governed by their interest in the subject; 13 per cent stated that they had chosen their subject out of curiosity; 5 per cent stated that they had chosen they subject "by default"; and 3 per cent claimed that their choice was based on their chances of success in the chosen subject. Only a small percentage of the participants made multiple choices, ticking more than one box: 22 per cent of the students made two choices, 2 per cent made three choices, and just 0.5 per cent made four choices. Only one variable had a significant impact on the average grade in the first semester: choice of course based on specific career aspirations. When this variable was included in model 6 (inclusion not presented), it was found to have a positive and significant impact ( $1 \%$ threshold). All other things being equal, the average grade of students who stated that they had chosen their course based on specific career aspirations was almost half a point higher than the average grade of other students (?0.49 coefficient). Therefore, the results indicate that a close match between the chosen subject and the student's career aspirations contributes significantly to success at university.

Analysis of success at the end of the academic year

Regression models 8 and 9: analysing determinants of success in semester 1 and semester 2

The estimates in this section apply to smaller numbers of students (69 students dropped out after the first-semester exams). Our study found that poor results in the January exams were the most significant reason for withdrawal, since the average grade of students who dropped out was 5.4 out of 20 at the end of the first semester.

We found a significant correlation between the two data collection periods (first and second semesters), although the assessed subjects were not the same, since the students took different modules in each semester. There was little variation in the student rankings, since the correlation for the sample was ?0.83 and varied very little in all three courses: ?0.85 in Law, ?0.85 in Psychology and ?0.84 in AES. Almost 70 per cent of the variance of grades in the second semester was explained by the level achieved in the first semester. The estimates of model 9 (Table 8), aiming to analyse the determinants of success in the second semester, were similar to the estimates relating to the first semester. The type of baccalaureate, the grade or distinction (honours), and age were found to be key determinants of success. The positive impact of performance in written comprehension and the absence of any effect of the logical reasoning score also need to be noted. In addition, the choice of course was not found to have any impact on results in the second semester (model not presented).

Table 8 compares the results of the two semesters based on different measurement scales. The model provides an indication of the relative progress of students across the year in terms of ranking and accounts for roughly 75 per cent of the 
Table 8 Analysis of variance of second-semester results

\begin{tabular}{|c|c|c|c|c|c|}
\hline \multirow[t]{2}{*}{ Reference category } & \multirow[t]{2}{*}{ Active category } & \multicolumn{2}{|c|}{$\begin{array}{l}\text { Model } 8 \\
(\mathrm{~N}=612): \\
\text { Determinants } \\
\text { of success in } \\
\text { semester } 1\end{array}$} & \multicolumn{2}{|c|}{$\begin{array}{l}\text { Model } 9 \\
(\mathrm{~N}=543)^{*} \text { : } \\
\text { Determinants } \\
\text { of success in } \\
\text { semester } 2\end{array}$} \\
\hline & & Coef. & Prob. & Coef. & Prob. \\
\hline Constant & & 4.0 & 0.00 & -0.5 & 0.29 \\
\hline \multicolumn{6}{|l|}{ Subject } \\
\hline \multirow[t]{2}{*}{ Law } & AES & +1.6 & 0.00 & -0.9 & 0.00 \\
\hline & Psychology & +3.3 & 0.00 & +1.2 & 0.00 \\
\hline Male & Female & +0.2 & 0.42 & +0.0 & 0.81 \\
\hline $\begin{array}{l}\text { Students who repeated one or } \\
\text { several years at secondary level }\end{array}$ & $\begin{array}{l}\text { Students who did not repeat } \\
\text { a year at secondary level }\end{array}$ & +0.7 & 0.00 & +0.2 & 0.25 \\
\hline Non-scholarship students & Scholarship students & -0.6 & -0.02 & -0.1 & 0.50 \\
\hline \multicolumn{6}{|l|}{ Type of baccalaureate } \\
\hline \multirow[t]{4}{*}{ Bac Pro } & Bac Techno & +0.3 & 0.56 & +0.3 & 0.40 \\
\hline & Bac L & +2.4 & 0.00 & +0.8 & 0.07 \\
\hline & Bac ES & +3.2 & 0.00 & +1.1 & 0.01 \\
\hline & Bac S & +4.4 & 0.00 & +1.3 & 0.00 \\
\hline Pass (without honours) & Honours $(\mathrm{AB}, \mathrm{B}$, or $\mathrm{TB})$ & +2.2 & 0.00 & +0.3 & 0.09 \\
\hline Written comprehension (DALF) & & +0.14 & 0.00 & +0.01 & 0.70 \\
\hline Raven's test (\% of success) & & +0.01 & 0.21 & +0.01 & 0.25 \\
\hline Average grade (first semester) & & & & +0.9 & 0.00 \\
\hline $\mathbf{R}^{2}$ & & 0.44 & & 0.75 & \\
\hline
\end{tabular}

variance of the grades in the second semester. Some of the variables have significant coefficients, including grade/distinction (honours) and type of baccalaureate.

Regression models 11 and 12: overall consideration of students’ first year at university

Finally, we examined the results for the academic year as a whole - i.e. final (average) grades for the year (model 11) ${ }^{12}$ and decision at the end of the year (model 12, not presented). The final (average) grade for the year was 9.4, with a standard deviation of 3 . The estimates in model 11 (Table 9) confirmed our previous findings, although it is important to note that the performance levels of technical and vocational baccalaureate holders no longer differed.

${ }^{12}$ Model 10 is not presented 
Table 9 Analysis of the variance of results across the year

\begin{tabular}{|c|c|c|c|}
\hline \multirow[t]{2}{*}{ Reference category } & \multirow[t]{2}{*}{ Active category } & \multicolumn{2}{|c|}{$\begin{array}{l}\text { Model } 11(\mathrm{~N}= \\
543): \\
\text { Overall first- } \\
\text { year grade }\end{array}$} \\
\hline & & Coef. & Prob. \\
\hline Constant & & 2.8 & 0.00 \\
\hline \multicolumn{4}{|l|}{ Subject } \\
\hline \multirow[t]{2}{*}{ Law } & AES & +2.2 & 0.00 \\
\hline & Psychology & +2.9 & 0.00 \\
\hline Male & Female & +0.2 & 0.38 \\
\hline $\begin{array}{l}\text { Students who repeated one or } \\
\text { several years at secondary level }\end{array}$ & $\begin{array}{l}\text { Students who did not repeat a year } \\
\text { at secondary level }\end{array}$ & +0.7 & 0.00 \\
\hline Non-scholarship students & Scholarship students & -0.5 & 0.02 \\
\hline \multicolumn{4}{|l|}{ Type of baccalaureate } \\
\hline \multirow[t]{3}{*}{ Bac Pro Bac Techno } & Bac L & +1.9 & 0.00 \\
\hline & Bac ES & +2.7 & 0.00 \\
\hline & Bac S & +3.7 & 0.00 \\
\hline Pass (without honours) & Honours (AB, B, or TB) & +2.1 & 0.00 \\
\hline Written comprehension (DALF) & & +0.14 & 0.00 \\
\hline Raven’s test (\% of success) & & +0.00 & 0.47 \\
\hline $\mathbf{R}^{2}$ & & 0.47 & \\
\hline
\end{tabular}

Path analysis

To determine the statistical relationships between the different groups of variables, we carried out a path analysis (Figure 3). The path analysis shows the direct or indirect effects of educational background and cognitive abilities on the results at the end of the year.

The first important finding shown in Figure 3 concerns the impact of educational background on the results at the end of the year. The impact of educational background is direct (very significant coefficient: 0.28 ), but also indirect, through cognitive abilities $(0.49 * 0.03)$. In other words, the educational background of students (baccalaureate grade and type of baccalaureate) had a significant impact on the results of the Raven test, which were found to have a limited impact (0.03) on success at the end of the year. Similarly, educational background significantly influenced the results in the DALF test, while the impact of cognitive abilities on the results of the DALF test was four times less significant. Academic performance in this area has a direct but limited impact on the results at the end of the year.

Finally, our study examined all of the determinants of success at the end of the first year together, based on a logistic regression model (not presented). The results highlighted an interesting phenomenon. The effect of academic level (written comprehension score) was less significant since the coefficient associated with the academic level variable was only significant at an 8 per cent threshold. By contrast, 


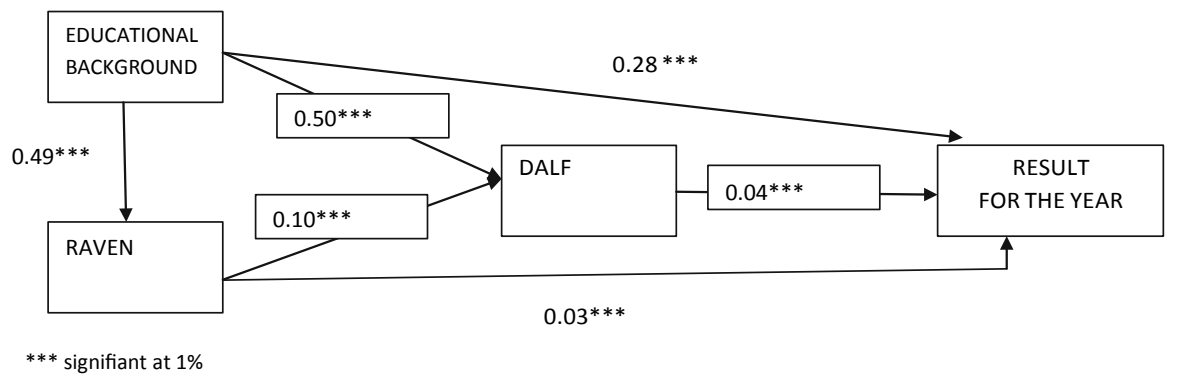

Fig. 3 Path analysis showing the relationships between educational background, academic performance, cognitive abilities and results at the end of the first year $(\mathrm{N}=543)$

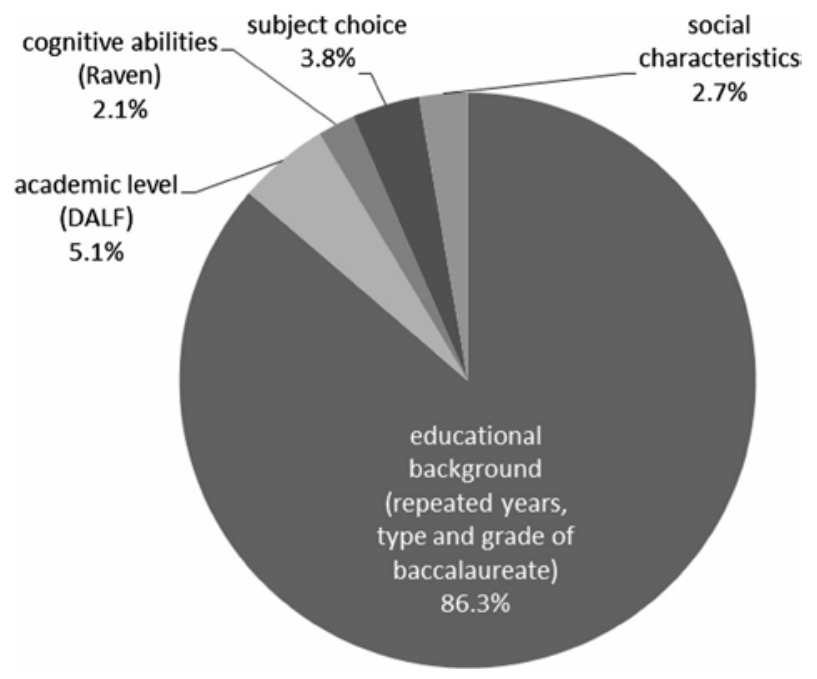

Fig. 4 Relative impact of student characteristics on success in the first year

performance in the Raven test tended to have a positive impact on the results (the probability of error associated with this coefficient was just $10 \%$ ). This is merely a trend, since the 5 per cent error threshold was not reached. Another key finding of this model was that the factors governing the choice of subject at university had an impact on success (which was not the case in our previous estimates relating to the grades achieved at the end of the year): the students who chose their subject based on specific career aspirations were 1.7 times more likely to succeed than other students.

\section{Conclusion}

Our study showed that the main factors determining success at the end of the first year of university were the variables related to educational background (repeated 
years, type of baccalaureate and baccalaureate grade). An analysis of the relative contribution of each group of factors to success yielded the pie chart shown in Figure 4. Intermediate models incorporating the different sets of explanatory variables can be used to assess the relative contribution of each group to the explanation of success (based on Nagelkerke's $\mathrm{R}^{2}$ ). Taken together, the variables account for roughly 30 per cent of the variance of the results (by deducting the contribution of enrolment in a particular course). The pie chart breaks down the variance of the results in terms of percentage according to the different sets of variables.

Our study shows the significant impact of educational background (repeated years, type of baccalaureate and grade), academic level (DALF; $5.1 \%$ of the explained variance), the factors governing the choice of subject (3.8\%), social characteristics (scholarship or no scholarship; less than 3\%), and cognitive ability (Raven; just over 2\%). We therefore infer that first-year students' academic skills and cognitive ability play a limited role in explaining differences of success, since the impact of these variables is apparent throughout students' educational career (and not just in higher education). To conclude, the performance of university students appears to be heavily influenced by the nature of their educational background. The results of our study highlight the factors governing the choice of subject at the end of secondary education. We found that subject choice based on specific career aspirations is an important factor associated with success, a significant finding which qualifies the impact of educational background. Beyond the effects associated with the type of baccalaureate, the independent impact of written comprehension abilities shows that the acquired skills, irrespective of secondary education, contribute to success at university. Finally, while the results suggest that cognitive ability has no independent impact on student results, it remains to be seen whether this also applies in subsequent years at Licence (roughly equivalent to a Bachelor degree) or Masters level. 


\section{References}

Astin, A. W. (1984). Student involvement: A developmental theory for higher education. Journal of College Student Personnel, 25(4), 297-308.

Barrouillet, P., Bernardin, S., \& Camos, V. (2004). Time constraints and resource sharing in adults' working memory spans. Journal of Experimental Psychology, 133(1), 83-100.

Barrouillet, P., Bernardin, S., Portrat, S., Vergauwe, E., \& Camos, V. (2007). Time and cognitive load in working memory. Journal of Experimental Psychology, 33(3), 570-585.

Barrouillet, P., Camos, V., Morlaix, S., \& Suchaut, B. (2008). Progressions scolaires, mémoire de travail et origine sociale: quels liens à l'école élémentaire? Revue Française de Pédagogie, 162, 5-14.

Beaupère, N., \& Boudesseul, G. (Eds) (2009). Sortir sans diplôme de l’Université. Comprendre les parcours d'étudiants “décrocheurs”. Collection études \& recherches. Paris: La Documentation Française.

Beduwe, C., \& Giret, J.-F. (2004). Le travail en cours d'études a-t-il une valeur professionnelle? Economie et Statistiques, 378-379, 55-83.

Borras, I. (2011). Le tutorat à l’université: peut-on forcer les étudiants à la réussite? Bref du CEREQ, 290, $1-4$.

Coulon, A. (1997). Le métier d'étudiant: l’entrée dans la vie universitaire. Paris: PUF.

Daneman, M., \& Carpenter, P. A. (1980). Individual differences in working memory and reading. Journal of Verbal Learning and Verbal Behavior, 19(4), 450-466.

Danner, M. (2000). A qui profite le tutorat mis en place dans le premier cycle universitaire? Les sciences de l'éducation pour l'ère nouvelle, 33(1), 25-41.

Duru-Bellat, M. (1995). Des tentatives de prédiction aux écueils de la prévention en matière d'échec scolaire en première année d'université. Savoir Education Formation, 3, 399-416.

Frickey, A., \& Primon, J. L. (2002). Jeunes issus de l'immigration: les diplômes de l'enseignement supérieur ne garantissent pas un égal accès au marché du travail. Formation Emploi, 79, 19-107.

Huteau, M., \& Lautrey, J. (1999). Evaluer l’intelligence. Psychométrie cognitive. Paris: Presses Universitaires de France (PUF).

Jensen, A. R. (1987). Individual differences in the Hick paradigm. In P. A. Vernon (Ed.), Speed of information processing and intelligence (pp. 101-175). Norwood: Ablex.

Lepine, R., Barrouillet, P., \& Camos, V. (2005). What makes working memory spans so predictive of high-level cognition? Psychonomic Bulletin \& Review, 12(1), 165-170.

MESR (Ministère de l'éducation nationale, de l'enseignement supérieur et de la recherche) (2010). Repères et Références Statistiques sur les enseignements, la formation et la recherche. Edition 2010. Paris: Ministère de l'éducation nationale, de l'enseignement supérieur et de la recherché (MESR) et Direction de l'évaluation, de la prospective et de la performance (DEPP).

Michaut, C. (2003). L’efficacité des dispositifs d’aide aux étudiants dans les universités. Recherche et Formation, 43, 101-113.

Prouteau, D. (2009). Parcours et réussite en licence des inscrits en L1 en 2004. Note d'information de la DPD, 23, 1-6.

Romainville, M. (2000). L’échec dans l'université de masse. Paris: L’Harmattan.

Shankland, R. (2009). Pédagogies nouvelles et compétences psychosociales. Paris: L’Harmattan.

Tinto, V. (1993). Leaving college: Rethinking the causes and cures of student attrition (2nd ed.). Chicago: University of Chicago Press.

Turner, M. L., \& Engle, R. W. (1989). Is working memory capacity task dependent? Journal of Memory and Language, 28(2), 127-154.

Vergauwe, E., Camos, V., \& Barrouillet, P. (2014). The effect of storage on processing: How is information maintained in working memory? Journal of Experimental Psychology, 40(4), 1072-1095. 